\title{
The Economic Guarantee of Logistic Connections Optimization at Railway Transport
}

\author{
Vasyl Kopytko ${ }^{1}$, Sergei Dziuba ${ }^{2}$, Maxym Mìshchenko ${ }^{3,}$, and Tetyana Shargun ${ }^{1}$ \\ ${ }^{1}$ Lviv Branch of DNURT, Department of Humanities and Social-Economic Training, I. Blazhkevych St., 12a, Lviv, Ukraine, 79052; \\ ${ }^{2}$ M.S. Polyakov Institute of Geotechnical Mechanics of NAS of Ukraine, Simferopolska St., 2a, Dnipro, Ukraine, 49005; \\ ${ }^{3}$ DNURT, Department of Economics and Management, Lazariana St., 2, Dnipro, Ukraine, 49010;
}

\begin{abstract}
The efficiency increasing of railway transport functioning is a main factor in the economic growth of the national economy. Material reserves are the main factor that defines the strategy of the enterprise and influences on the economic optimization level of logistic connections in general. Waste on deficiency and expense of storing the taken out from the main turnover material reserves redouble the economic situation. In this research the sources of the arising an uncertainty by taking a decision about economic optimization of logistic connections and working out methods of need determination in conditions of a certain uncertainty that will be led to improvement of the economic effectiveness of activity are determined. The best methods that may be used for this purpose are analysis of temporary series, multiple regression and correlation analysis, pattern recognition. The paper presents the results of research that allow, based on the built neuro-fuzzy model, to evaluate the dependence of macroeconomic indicators of the national economy of Ukraine on the indicators characterizing its economic situation in order to improve the control efficiency of logistics systems. The built neuro-fuzzy model, unlike existing models, allows reproducing the complex nonlinear dependences.
\end{abstract}

\section{Introduction}

The economic situation of the state, its development and stability to effectively integrate into the world economic community depends on its resource potential and its effective use. The resource potential includes natural environment, raw materials, quantity and quality of manpower, intelligent and industrial potential created at the time of economic state assessing, as well as availability of infrastructure for its development.

The paper presents the results of research that allow, based on the built neuro-fuzzy model, to evaluate the dependence of macroeconomic indicators of the national economy of Ukraine on the indicators characterizing its economic situation in order to improve the control efficiency of logistics systems. The built neuro-fuzzy model, unlike existing models, allows reproducing the complex nonlinear dependences.

\section{Development of mechanism for monitoring economic situation and development prosepcts of the country based on modelling of macroeconomic processes using intelligent technologies}

The efficiency increasing of railway transport functioning is a main factor in the economic growth of the national economy. Material reserves are the main factor that defines the strategy of the enterprise and influences on the economic optimization level of logistic connections in general. Waste on deficiency and expense of storing the taken out from the main turnover material reserves redouble the economic situation. In this research the sources of the arising an uncertainty by taking a decision about economic optimization of logistic connections and working out methods of need determination in conditions of a certain uncertainty that will be led to improvement of the economic effectiveness of activity are determined. The best methods that may be used for this purpose are analysis of temporary series, multiple regression and correlation analysis, pattern recognition.

In international practice, there are several approaches to determining the socio-economic condition of the state and the prospects for its positive development. However, numerous theoretical studies do not provide a complete picture of the state development; while determining its prospects, they use, as a rule, the production functions such as [1]:

$$
W=f(L, A)
$$

where $L$ - state labour potential; $A$ - productive assets owned by the state.

Indicators of a number of studies have different focus (economic, technical, technological, social, etc.), which complicates the task of determining the development vector. That is why the purpose of this work is to develop a mechanism for monitoring the economic situation and development prospects based on modelling of mac-

\footnotetext{
* Corresponding author: mmi@ua.fm
} 
roeconomic processes using intelligent technologies. At present the existing approaches to determine the state of the country include the following ones. The position of each of the states that make up the International Monetary Fund (IMF) is assessed by the indicator system that includes more than 20 indicators of economic, environmental and social conditions [2]. Herewith the indicators are grouped according to such classification features as poverty and social sphere state (population, GNI per capita, poverty, urban population, life expectancy, infant mortality, child malnutrition, access to improved water, illiteracy, general primary education), level of key economic indicators (exports of goods and services, gross domestic investment, gross national savings, current account balance, interest payments, total debt, total debt service), long-term development trends (GNI growth rate per capita), economy structure (agriculture, industry, production, services, private consumption, state consumption, imports of goods and services), level of prices and public finances (consumer price, GDP deflator level, current revenues, current budget balance, total surplus/deficit), trade conditions (total exports, total imports, food, fuel, ore and metals, production), external payments position (balance of resources, net income, net operating transfers, financial instruments, changes in net reserves, reserves, exchange rate), foreign debt level (total debt to maturity, long-term external debt, shortterm debt, total debt to maturity on the World Bank loans, total debt to maturity on the International Development Association loans, total debt service, official grants, private lenders, foreign direct investment, portfolio property, transactions, payments to maturity, principal debt repayment, net flows, interest payments, net transfers). Since the level of indicators listed above by country has a great difference, the IMF proposed a classification of countries. Namely, with the analytical purpose the IMF divides countries by groups of income, i.e. by gross national income per capita into the following groups: low-income countries (GNI per capita of less than 745 dollars), the countries with income below average (746 - 2975 dollars), countries with incomes above the average (2976 - 9205 dollars) and those with high income (9206 dollars or higher).

The study of interrelation between the growth rate of GDP per person and its level (Fig. 1) confirms the need for country division into income groups prior to analysing other indicators, such as economic growth. The relationship between the growth of GDP per capita and the level of GDP is confirmed by sufficiently high coefficient of multiple correlation $R^{2}(0.5278)$ [3]. Dependence is characterized by the following equation:

$$
\Delta G D P=-2,3841 \cdot \ln (x)+27,832
$$

where $\triangle G D P$ - growth rate of GDP per capita (\%); $x$ - GDP per capita ( $\$ /$ person).

That is, the higher the level of GDP per capita, the lower the growth rate. It follows that, to assess certain result, the growth performance analysis should be conducted within each classification group.

Furthermore IMF classifies countries by region (geographic location) and by level of foreign debt.
Classification of countries in terms of foreign debt involves the grouping of countries with low, average, moderate and high level of debt.

Herewith the average level of debt means that the ratio of the present value of debt to gross national income exceeds $80 \%$ or the ratio of the present value of debt to exports exceeds $220 \%$ [1].

This classification is proposed by UNO within Development Program [4]. According to this program such tasks include the following: elimination of poverty and famine; provision of basic primary education; stimulation of gender equality; reducing child mortality; improvement of maternal health; control of AIDS, malaria and other diseases; maintenance of ecological balance; global partnership for development; achieved common indicators (population, GNI, GNI per capita, literacy, final birth rate, life expectancy, aid, reducing foreign debt, increasing investment and trade in $\%$ to GDP).

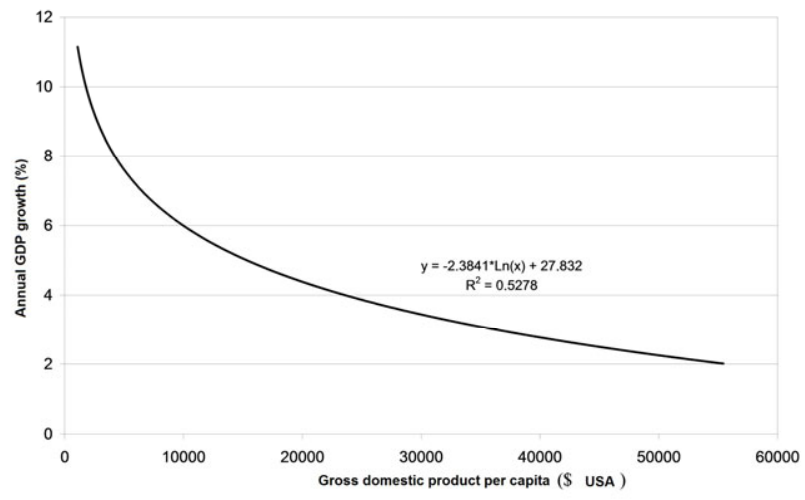

Fig. 1. Dependence of GDP growth rate on GDP per capita

One of the most influential international financial organizations is Multilateral Investment Guarantee Agency (MIGA), which insures foreign investment (direct and portfolio) and ensures their return in the event of insolvency of the country-borrower in the amount of $90 \%$ of the investment, giving such guarantees for 15-20 years [4]. Activities of the above Agency are associated with the risk of a particular country. In this context, Multilateral Investment Guarantee Agency analyses the country in terms of these commitments, determining the commercial, political and economic risks in each country, and guarantees the return of foreign investment [5]. Classification of factors that characterize the state of the country in terms of investment risk is presented in Fig. 2. Herewith the Multilateral Investment Guarantee Agency divides all countries in terms of political risk into seven groups (risk increases from the first to the seventh group), level of commercial risk - into three groups (A, $\mathrm{B}$ and $\mathrm{C}$, where the most risky countries are those of group $\mathrm{C}$ ), risk of war, expropriation and government action - into seven groups (the seventh one has the highest risk).

The process of creation of the European Union demanded determining the development indicators, which control an objective identity of any country in the group of countries that may enter the union without creating imbalance in the costs of countries-participants for stabilization of the EU economy as a whole. 


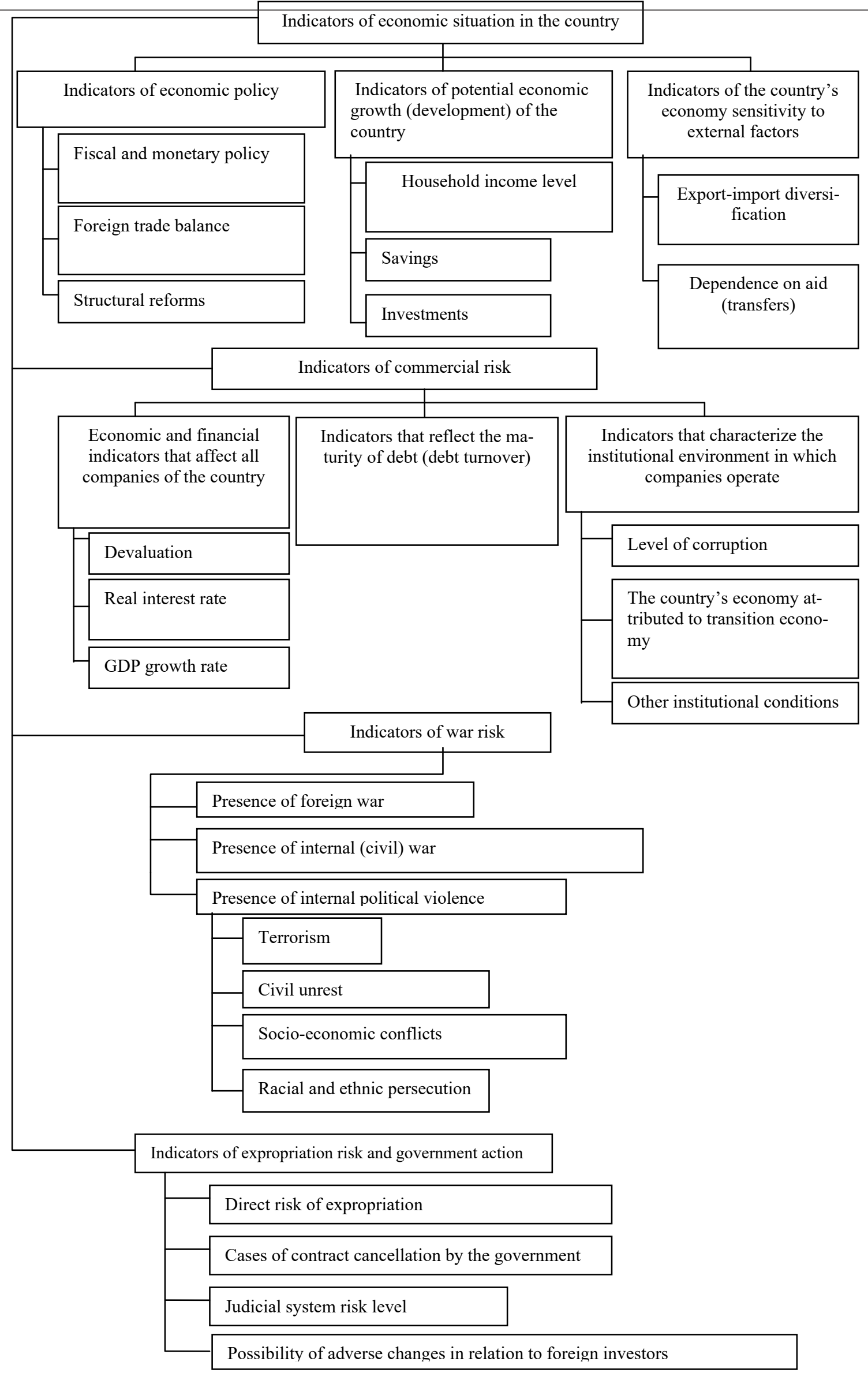

Fig. 2. Indicators of investment risk in the country economy 
These indicators include the inflation rate (which must not exceed by $1.5 \%$ the average inflation rate of three EU countries characterized with highest price stability); the state budget deficit (which must not exceed $3 \%$ of GDP at the ratio of public debt to GDP of no more than $60 \%$ ); the level of long-term interest rates should not be higher than $2 \%$ of the average level of the index in three EU countries that have achieved the highest price stability [6].

Continuing analysis of approaches to the assessment of country position and prospects of its development, it should be noted that, in order to monitor key growth indicators, each country develops a system of national accounts, which makes it possible to track a series of interrelated processes and phenomena in the economy (volume and structure of production, income, consumption, capital and finance formation) [7].

\section{Classification of economic security factors}

In the current research [8-10] the economic security factors (Figure 3) are divided into three groups: economic independence; economic stability and strength; ability for self-development and progress.

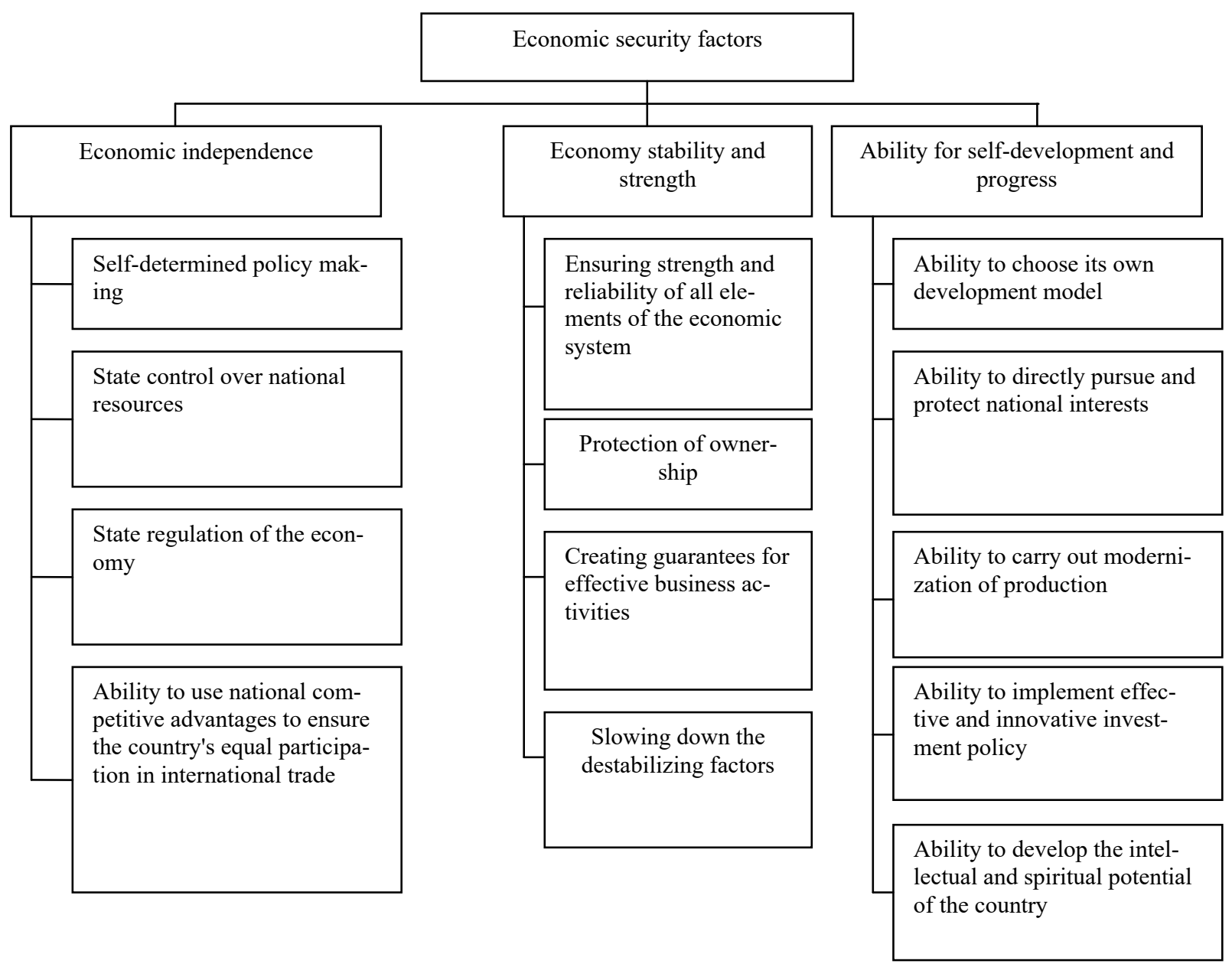

Fig. 3. Classification of economic security factors

The first group includes such factors as the country's ability to form its economic policies, the ability to control the national resources, the ability for state regulation of the economy and the ability to use national competitive advantages to ensure the country's equal participation in international trade.

Apparently, it is necessary to specify these factors and find the indicators that would characterize the level of these factors.

The second group of factors in contemporary studies includes those affecting the economy stability and strength. Namely, the ability of a country to ensure strength and reliability of all elements of the economic system; protection of ownership; country's guarantees for effective business activities; the ability of a country to slow down destabilizing factors.

The third group of factors included those providing self-development and progress. Namely, the opportunity and the ability to choose its own model of development; the ability to promote and protect its own national interests; the ability to modernize production, to pursue innovative and effective investment policy, to develop the intellectual and spiritual potential.

All these factors are qualitative in nature (ability, opportunity, etc.) and can be measured only using the expert method. However, indirectly the level of these fac- 
tors can be identified with the help of indicators that answer the question whether the goal is reached, or whether there are conditions for its achievement. Table 1 shows the indicators, which, in our opinion, can indirectly determine the state's ability to develop.

Each of the above approaches to assess the economic situation of the country is complementary and designed for specific purposes (country's solvency assessment, its reliability for investors, stability of its economy). The indicators used for the specified purpose are the result- ant, may be used as those for control of the country position and do not include factors subject to management on the level of current (operational) solutions. In other words, these are the indicators that characterize the result of average and long term development. To ensure operational control is necessary to determine the factors that affect the resulting indicators, level of influence of these factors on them and create operational tasks directed at positive current results in achieving the average and long-term goals.

Table 1. Indicators characterizing the level of economic security factors

\begin{tabular}{|c|c|c|c|}
\hline & & Factor & Factor level indicator \\
\hline 1 & \multicolumn{3}{|c|}{ Economic independence } \\
\hline & 1.1. & Self-determined policy making & $\begin{array}{l}\text { 1.1.1. Capital share of the state and national investors in the } \\
\text { economy (incl. by activities) }\end{array}$ \\
\hline & 1.2. & State control over national resources & $\begin{array}{l}\text { 1. 2.1. Share of resources controlled by the state and national } \\
\text { investor in the economy (incl. by activities) }\end{array}$ \\
\hline & 1.3. & State regulation of economy & $\begin{array}{l}\text { 1. 3.1. Share of budget intended to finance the material produc- } \\
\text { tion sectors (industry, agriculture, construction) }\end{array}$ \\
\hline & 1.4. & $\begin{array}{l}\text { Ability to use national competitive advantages } \\
\text { to ensure equal participation in international } \\
\text { trade }\end{array}$ & $\begin{array}{l}\text { 1.4.1. Share of export of certain goods and services in world } \\
\text { trade } \\
\text { 1.4.2. Exports in \% of GDP } \\
\text { 1.4.3. Balance of visible trade of countries }\end{array}$ \\
\hline \multirow[t]{5}{*}{2} & \multicolumn{3}{|c|}{ Economy stability and strength } \\
\hline & 2.1. & $\begin{array}{l}\text { Ensuring strength and reliability of all elements } \\
\text { of the economic system }\end{array}$ & $\begin{array}{l}\text { 2.1.1. Financial stability of enterprises of the country's economy } \\
2.1 .2 \text {. Labor productivity in the economy }\end{array}$ \\
\hline & 2.2. & Protection of ownership & 2.2.1. Economy structure by form of ownership \\
\hline & 2.3. & $\begin{array}{l}\text { Creating guarantees for effective entrepreneuri- } \\
\text { al activity }\end{array}$ & 2.3.1. Labour productivity by form of ownership \\
\hline & 2.4. & Slowing down the destabilizing factors & 2.4.1. Inflation rate in the country \\
\hline \multirow[t]{6}{*}{3.} & \multicolumn{3}{|c|}{ Ability for self-development and progress } \\
\hline & 3.1. & Ability to choose its own development model & $\begin{array}{l}\text { 3.1.1. Place of the country in the world economy by key indica- } \\
\text { tors }\end{array}$ \\
\hline & 3.2. & $\begin{array}{l}\text { Ability to directly pursue and protect national } \\
\text { interests }\end{array}$ & $\begin{array}{l}\text { 3.2.1. Place of the country in the world economy by key indica- } \\
\text { tors }\end{array}$ \\
\hline & 3.3. & Ability to carry out modernization of production & $\begin{array}{l}\text { 3.3.1. Gross national income per capita } \\
\text { 3.3.2. Exports in \% of GDP } \\
\text { 3.3.3. Balance of visible trade } \\
\text { 3.3.4. Export structure }\end{array}$ \\
\hline & 3.4. & $\begin{array}{l}\text { Ability to implement effective and innovative } \\
\text { investment policy }\end{array}$ & $\begin{array}{l}\text { 3.4.1. Gross national income per capita } \\
\text { 3.4.2. Exports in } \% \text { of GDP } \\
\text { 3.4.3. Balance of visible trade } \\
\text { 3.4.4. Export structure }\end{array}$ \\
\hline & 3.5 . & $\begin{array}{l}\text { Ability to develop the intellectual and spiritual } \\
\text { potential of the country }\end{array}$ & $\begin{array}{l}\text { 3.5.1. Science expenditure level } \\
\text { 3.5.2. Culture expenditure level } \\
\text { 3.5.3. Education expenditure level }\end{array}$ \\
\hline
\end{tabular}

The state of socio-economic security is affected by the stability of the national currency, the level of balance of payments deficits, the level of internal and external debt. This, in turn, depends on the export potential of the country and the nature of exports (raw materials, products of processing industry, high technology, services). Export volumes enable the country to develop import without negative consequences for the national currency. The level of imports indicates the country's integration into the world economic community, the openness of its economy. The restraint of import growth indicates the inability of the country to develop its export potential and provide excess growth rate of exports of goods and services over their imports. Therefore, when describing the socio- economic development, it is advisable to analyse the above figures. The increased indicator of exports of goods and services as percentage of GDP indicates the innovation direction of the country's economy development, its increased competitiveness in the global market for goods and services, demand for the national currency of the country.

Analysis of economy of Ukraine conducted according to [7] shows the following. Dependency of GDP growth rates on the tax burden change (incl. and escl. subsidies) and tax revenue are characterized (with high impact coefficient: $R^{2} \geq 0,8$ ) with polynomial dependencies, indicating the significant fluctuations in these indicators. The same can be said of the relationship between GDP and 
inflation, which can be approximated by a polynomial curve $\left(R^{2}=0,5235\right)$. The most stable character among the set dependencies is shown by GDP dependency on net capital inflow, which is characterized with the third degree polynomial dependence at $R^{2}=0,77$. This shows that the impact of factors on these indicators of the country's economy development as a complex system is characterized by a complex nonlinear dependencies of its outputs on inputs with fuzzy statistical information. Therefore, to build and analyse the model of impact of macroeconomic factors on these indicators it is advisable to use the neurofuzzy technology [12 - 14].

As the resultant indicators, we considered the gross national income (GNI) and the gross domestic product (GDP) per capita, as these indicators are the most generalizing when determining the economic situation of the country. The factors affecting the level of GDP per capita include the following: inflation level (X1), tax burden (X2), tax revenue share in the budget revenues (X3), real interest rate on deposits (X4), exports of goods and services as percentage of GDP (X5), import of goods and services as percentage of GDP (X6).

Inflation level (X1) characterizes the rationality of many processes in the economy. However, given that, according to classical theory [11], inflation is a manifestation of the cost crisis (increased cost of production of goods and services) or production volume crisis (production slump and the associated emergence of deficit and higher prices), the inflation indicator requires more indepth study to identify factors that led to this level.

The tax burden (X2) is an indicator that should be optimized: positive impact of this factor on output has its upper limit, whereupon the share of shadow economy increases, tax revenue to state and local budgets reduces, net capital inflows to countries decreases. Establishing the optimal level of this indicator requires a detailed study of the country's tax system.

The tax revenue share in the budget revenues (X3) on the one hand characterizes the efficiency of the tax system of the state and on the other hand - the centralization of functions assumed by the state and local budgets (public administration, defence, health and environmental protection, development of science, education, culture, state participation in programs supporting the development of certain economic sectors, subsidies to loss- making industries). The study of these processes is the subject of special researches.

An important indicator of the country's position is the real interest rate on deposits (X4). As it is known, the deposit rate is the lower margin of investment efficiency. In addition, the real deposit rate is an indicator that determines the feasibility of forming the capital as investments into the banking system and hence the availability of credit resources in the country, which is an important component of successful activity of enterprises. Study if this indicator consists of two parts: study of factors affecting inflation, and study of efficiency of the country's banking system.

Exports of goods and services (X5) describes the export potential of the country and, affecting its economic state, in turn, depends on the availability of innovative infrastructure, competitiveness of domestic enterprises, development of foreign trade, the level of its liberalization enshrined in law.

Imports of goods and services (X6) show the openness of the economy and the competition level. Indices of exports and imports are consolidated in the index of balance of goods and services, which should be positive. The study of these indicators by the structure of exports and imports, as well as certain types of similar products (e.g., metal, grains, etc.) allows ascertaining the effectiveness of export and import activities, pricing policy of the companies, deficiencies in the regulation of foreign trade.

\section{Development of gdp dependence model in relation to the selected macroeconomic factors}

At the first stage of model building we analyse the relationship between inputs (X1, X2, X3, X4, X5, X6, X7, $\mathrm{X} 8$ ) and outputs (GDP), according to available annual data of the State Statistics Committee of Ukraine, the National Bank of Ukraine, for the period 10 years [7, 15], which are listed in Table 2.

Let us consider the GDP dependency model in relation to the selected macroeconomic factors $\mathrm{X} 1, \mathrm{X} 2, \mathrm{X} 3$, $\mathrm{X} 4, \mathrm{X} 5, \mathrm{X} 6, \mathrm{X} 7, \mathrm{X} 8$ as the following:

$$
\mathrm{GDP}=\mathrm{F}(\mathrm{X} 1, \mathrm{X} 2, \mathrm{X} 3, \mathrm{X} 4, \mathrm{X} 5, \mathrm{X} 6, \mathrm{X} 7, \mathrm{X} 8), \mathrm{XI}_{\min } \leq \mathrm{XI} \leq \mathrm{XI}_{\max }, \mathrm{I}=1, \ldots, 8
$$

We start building the explicit model (3) by forming the fuzzy productive knowledge base, which is a set of fuzzy expert linguistic rules of IF-THEN type that bind together the linguistic evaluations of input variables $(\mathrm{X} 1, \mathrm{X} 2, \mathrm{X} 3$, X4, X5, X6, X7, X8) and output variable of GDP. Linguistic evaluations will be obtained on the basis of statistic data set out in Table 2.

To build the explicit model (3), we formalize the linguistic evaluations "Low", "Lower than average" and others using the membership functions. We set these functions in the following form [14]

$$
\mu^{T}(x)=\frac{1}{1+\left(\frac{x-b}{c}\right)^{2}}
$$

where $\mu^{T}(x)$ is the number in the range [0,1], which describes the subjective measure of $x$ value compliance with fuzzy term ( "low", "lower than average" et al.), $b$ and $c$ parameters, first selected by an expert and then configured to experimental data: $b$ - coordinate of maximum of the function $\mu^{T}(x)$, herewith $\mu^{T}(b)=1, c$ factor of concentration - extension of the function $\mu^{T}(x)$. 
Table 2. Annual data of key macroeconomic indicators

\begin{tabular}{|l|c|c|c|c|c|c|c|c|c|}
\hline Years & $\begin{array}{c}\text { GDP } \\
\text { UAH/person }\end{array}$ & $\begin{array}{c}\text { X1 } \\
\text { \% p.a. }\end{array}$ & $\mathbf{X 2}$ & $\mathbf{X 3}$ & $\begin{array}{c}\mathbf{X 4} \\
\%\end{array}$ & $\begin{array}{c}\text { X5 } \\
\text { mln. UAH }\end{array}$ & $\begin{array}{c}\text { X6 } \\
\text { mln. UAH }\end{array}$ & $\begin{array}{c}\text { X7 } \\
\text { mln. \$ }\end{array}$ & $\begin{array}{c}\text { X8 } \\
\text { In. } \\
\text { UAH }\end{array}$ \\
\hline Year 1 & 1595.9 & 139.7 & 0.12 & 0.8 & -5.4 & 60455.9 & 34740.4 & 896.9 & 4159.9 \\
\hline Year 2 & 1843.8 & 110.1 & 0.1 & 0.7 & 24.2 & 59552.5 & 35219.5 & 1438.2 & 6447.8 \\
\hline Year 3 & 2041.8 & 120.0 & 0.1 & 0.8 & 2.3 & 93601.7 & 55197.0 & 2063.6 & 2113.7 \\
\hline Year 4 & 2624.0 & 119.2 & 0.1 & 0.8 & 1.5 & 122205.9 & 67599.6 & 2810.7 & 1965.3 \\
\hline Year 5 & 3492.2 & 125.8 & 0.07 & 0.6 & -16.6 & 106200.0 & 97643.0 & 3875.0 & -969.3 \\
\hline Year 6 & 4236.3 & 106.1 & 0.05 & 0.7 & 4.7 & 113245.0 & 109924.0 & 4801.0 & 593.4 \\
\hline Year 7 & 4724.1 & 99.4 & 0.05 & 0.7 & 7.5 & 124392.0 & 114501.0 & 5924.0 & -1635.4 \\
\hline Year 8 & 5640.2 & 108.2 & 0.05 & 0.7 & -0.2 & 154394.0 & 147525.0 & 7566.0 & 506.7 \\
\hline Year 9 & 7327.2 & 112.3 & 0.04 & 0.7 & -4.4 & 211248.0 & 185318.0 & 9606.0 & 11009.0 \\
\hline $\begin{array}{l}\text { Year } \\
10\end{array}$ & 9095.1 & 110.3 & 0.04 & 0.7 & -2.3 & 227252.0 & 223555.0 & 17311.0 & 7806.3 \\
\hline
\end{tabular}

As an example, Figure 4 shows the membership functions for X1 variable.

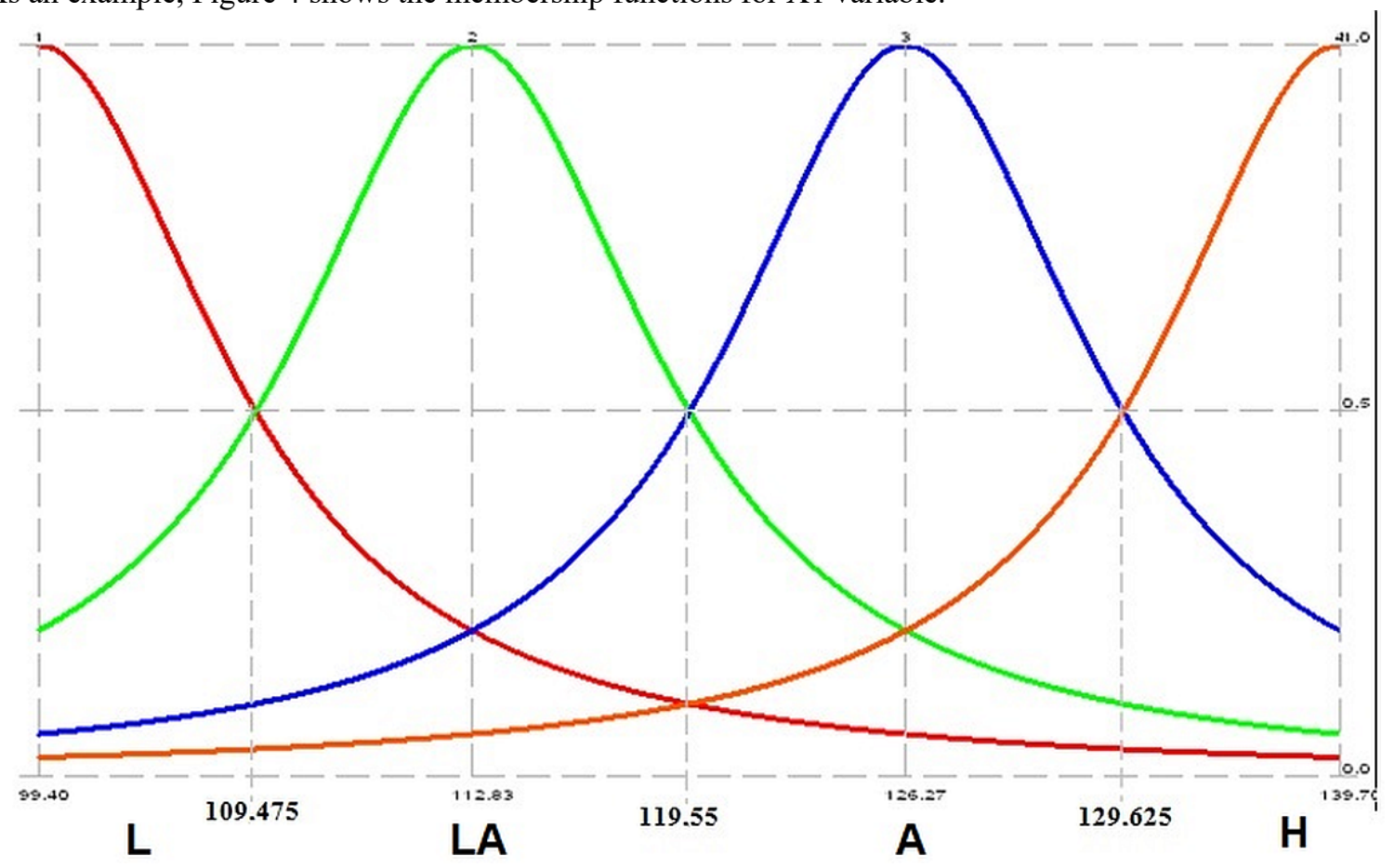

Fig. 4. Membership functions of X1variable values for corresponding fuzzy term:

$L$ - low, $L A$ - lower than average, $A$ - average, $H$ - high

Next, using the membership functions and the technology [12 - 14] we introduce, according to [12], the model (3) in an explicit form

$$
G D P=\frac{\sum_{k=1}^{5} d_{k} \mu\left(G D P_{k}\right)}{\sum_{\kappa=1}^{5} \mu\left(G D P_{k}\right)}
$$

where $G D P_{k}$ - value of GDP variable in the range $D_{k}$, $k=1, \ldots, 5(\operatorname{model}(5,6,7,8,9))$ 


$$
\begin{gathered}
\mu\left(G D P_{1}\right)= \\
=\min \left\{\begin{array}{l}
1, \\
w_{1} \mu_{1 B}(X 1) \cdot \mu_{2 B}(X 2) \cdot \mu_{3 B}(X 3) \cdot \mu_{4 H C}(X 4) \cdot \mu_{5 H}(X 5) \cdot \mu_{6 H}(X 6) \cdot \mu_{7 H}(X 7) \cdot \mu_{8 H C}(X 8)+ \\
+w_{2} \mu_{1 H C}(X 1) \cdot \mu_{2 B}(X 2) \cdot \mu_{3 C}(X 3) \cdot \mu_{4 B}(X 4) \cdot \mu_{5 H}(X 5) \cdot \mu_{6 H}(X 6) \cdot \mu_{7 H}(X 7) \cdot \mu_{8 C}(X 8)+ \\
+w_{3} \mu_{1 C}(X 1) \cdot \mu_{2 B}(X 2) \cdot \mu_{3 B}(X 3) \cdot \mu_{4 H C}(X 4) \cdot \mu_{5 H}(X 5) \cdot \mu_{6 H}(X 6) \cdot \mu_{7 H}(X 7) \cdot \mu_{8 H C}(X 8)+ \\
+w_{4} \mu_{1 H C}(X 1) \cdot \mu_{2 B}(X 2) \cdot \mu_{3 B}(X 3) \cdot \mu_{4 H C}(X 4) \cdot \mu_{5 H C}(X 5) \cdot \mu_{6 H}(X 6) \cdot \mu_{7 H}(X 7) \cdot \mu_{8 H C}(X 8)
\end{array}\right\} \\
=\min \left\{\begin{array}{l}
1, \quad \mu D P)= \\
w_{5} \mu_{1 C}(X 1) \cdot \mu_{2 H C}(X 2) \cdot \mu_{3 H}(X 3) \cdot \mu_{4 H}(X 4) \cdot \mu_{5 H C}(X 5) \cdot \mu_{6 H C}(X 6) \cdot \mu_{7 H}(X 7) \cdot \mu_{8 H}(X 8)+ \\
+w_{6} \mu_{1 H}(X 1) \cdot \mu_{2 H}(X 2) \cdot \mu_{3 C}(X 3) \cdot \mu_{4 C}(X 4) \cdot \mu_{5 H C}(X 5) \cdot \mu_{6 H C}(X 6) \cdot \mu_{7 H}(X 7) \cdot \mu_{8 H}(X 8)
\end{array}\right\} \\
=\min \left\{\begin{array}{l}
1, \\
w_{7} \mu_{1}(X 1) \cdot \mu_{2 H}(X 2) \cdot \mu_{3 C}(X 3) \cdot \mu_{4 C}(X 4) \cdot \mu_{5 H C}(X 5) \cdot \mu_{6 H C}(X 6) \cdot \mu_{7 H C}(X 7) \cdot \mu_{8 H}(X 8)+ \\
+w_{8} \mu_{1 H}(X 1) \cdot \mu_{2 H}(X 2) \cdot \mu_{3 C}(X 3) \cdot \mu_{4 H C}(X 4) \cdot \mu_{5 C}(X 5) \cdot \mu_{6 C}(X 6) \cdot \mu_{7 H C}(X 7) \cdot \mu_{8 H}(X 8)
\end{array}\right\} \\
\mu\left(G D P_{4}\right)=w_{9} \mu_{1 H C}(X 1) \cdot \mu_{2 H}(X 2) \cdot \mu_{3 C}(X 3) \cdot \mu_{4 H C}(X 4) \cdot \mu_{5 B}(X 5) \cdot \mu_{6 B}(X 6) \cdot \mu_{7 C}(X 7) \cdot \mu_{8 B}(X 8)
\end{gathered}
$$

Here $w_{i}$ is the number in the range $[0,1]$, which describes a subjective measure of expert's confidence with respect to the statement with the number $i$ from the knowledge base, that is the significance of the $i-$ th rule.

It should be noted that use of the model (4) allows reliable assessment of the impact of changes in selected indicators on GDP. And the better the initial values for $b$, $c, w$ parameters are selected, the closer to the experimental data the model (3) will be.

In order to obtain the model (4), rather close to the experimental data, one conducts its setting, i.e. selects such $b, c, w$ parameters, which ensure minimal deviation of distance $\Delta$ between the model (theoretical ones, derived from model (4)) and the experimental data. $\Delta$ value, which is the standard deviation of the theoretical output from the experimental one, is used for model setting quality assessment.

To set the model, we used the gradient method modification in the case of undifferentiated functions, the socalled Shor's r-algorithm [12] with precision $\varepsilon=0.001$.

Let us consider the impact of certain factors on the level of gross domestic product (GDP) per capita. As it is known, the inflation level (X1) causes a negative impact on GDP level. Herewith there are two ways of the negative impact of inflation on GDP. First, if during GDP calculation the inflation is not taken into account, the GDP indicator, as well as other cost indicators, increases without quality positive change in the country's economy, only due to price rise. On the other hand, high inflation is the indicator of inefficient functioning of the economy, which is manifested in relatively high cost of production of goods and services or their deficiency due to lower production volumes. The results of the analysis carried out by means of neuro-fuzzy technologies show that in Ukraine GDP per capita declines with rising inflation, which corresponds to the second of the above ways of inflation impact on GDP. Growth of export of goods and services (X5) has a positive effect on GDP per capita, as it indicates the rise in production of competitive goods and services, liberalization of foreign trade for enterprises, increased demand for the national currency in the global currency market. However, one should not be limited to the analysis of total exports. During detailed analysis of the impact of export on GDP it is necessary to examine its structure, identify the raw material and high-tech components of exports, focus on the level of services export growth. It should be noted that in Ukraine, according to the State Statistics Committee of Ukraine, as of 2005 the raw material component of export of goods makes $13.7 \%, 8.8 \%$ are for export of the plant products, $40.9 \%$ of exports are non-precious metals of products thereof [5]. Herewith the export of instruments and equipment is $0.4 \%$, vehicles and road equipment $4.8 \%$ and mechanical equipment $-8.3 \%$ [5]. Regarding export of services, $32 \%$ of them are transport services of pipeline transportation [5]. In view of the fact that in recent years the structure of export has not changed, the export growth does not lead to qualitative changes in GDP (Fig. 5). 


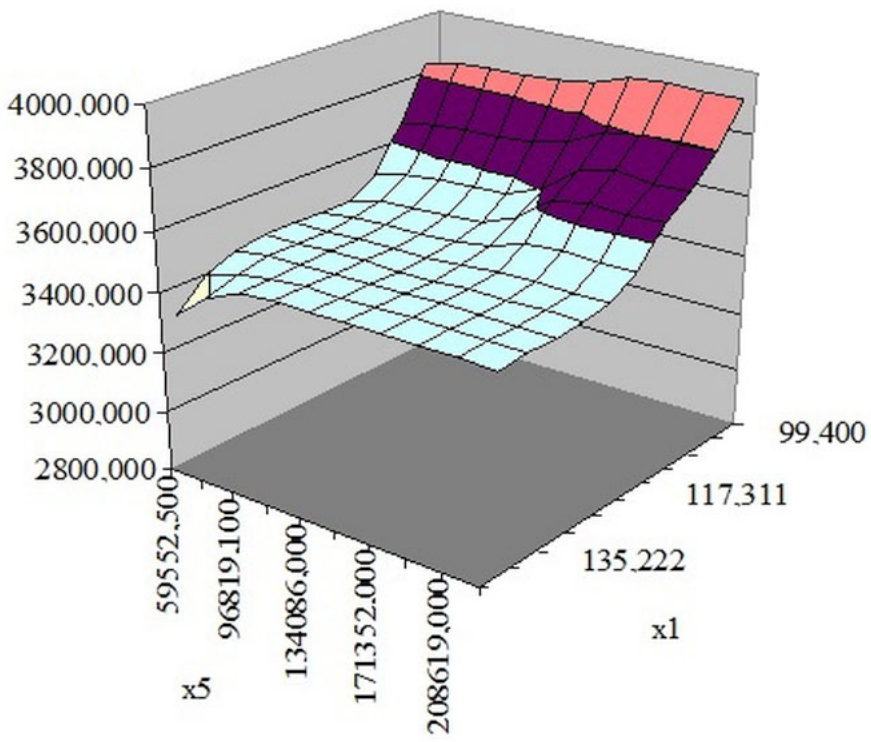

Fig. 5. GDP dependence on inflation and exports of goods and services

Therefore, at the moment, in order to increase GDP, it is necessary to restructure the export potential of the country. Growth of import of goods and services (X6) is the objective consequence of integration processes and globalization of the world economy. If the import volumes are accompanied by GDP growth, this shows the positive effects of the country's integration into the world economic community and that export is growing more rapidly than import. According to the analysis carried out using neuro-fuzzy technology, in Ukraine when import (X6) increases, GDP per capita remains virtually unchanged, indicating a lack of effective export potential formation policy. The growth of budget deficit has also the negative impact on GDP (X8) (Fig. 6).

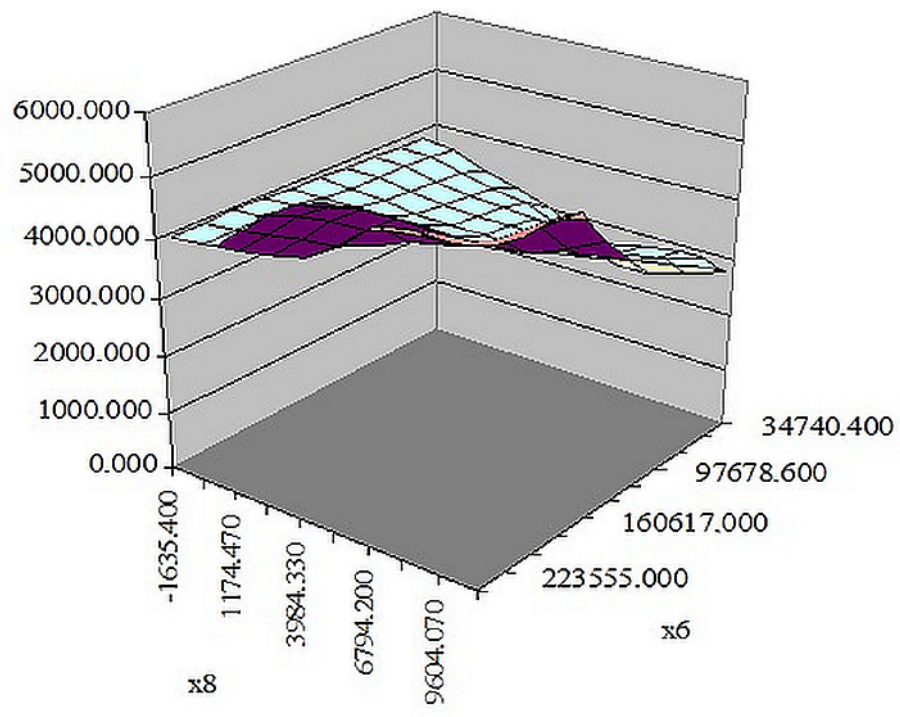

Fig. 6. GDP dependence on budget deficit and import of goods and services

The level of gross national income (GNI) per capita reflects the level of labour productivity in a country, the level of wages and income, falling to an average distribution per citizen through the existing distribution mechanisms in the country. Together with other indicators, defined as the average, it is characterized by a number of disadvantages associated with the lack of consideration of the distribution structure. However, it is generally recognized indicator that characterizes the welfare of the country as a whole. This is confirmed by comparative analysis of the socio-economic condition of the countries according to the World Bank data [2].
Gross national income per capita first of all is affected by the development of entrepreneurship in the country, which is directly related to tax burden (X2), real interest rate on deposits (X4) and direct investment in Ukraine (X7). The positive impact of foreign investments on GNI depends not only and not so much on their volumes, but on the effectiveness of their use. Therefore, Fig. 7 shows in these days a decline in efficiency of foreign investment coming into the country and not accompanied by the latest technology in the manufacturing sector. 


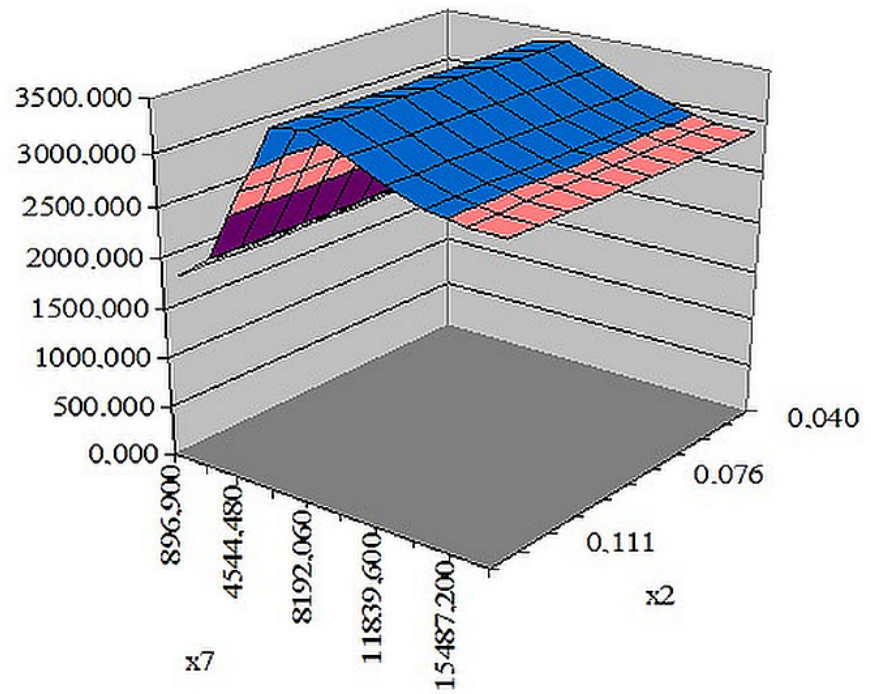

Fig. 7. GNI dependence on tax burden rate and amount of direct investment into the country

Real deposit rate according to the analysis (Figure 8) does not affect GNI, which is connected, first of all, with low capacity of the financial sector, which has been de- veloping only since 1991 and is not directed at investment financing of the companies.

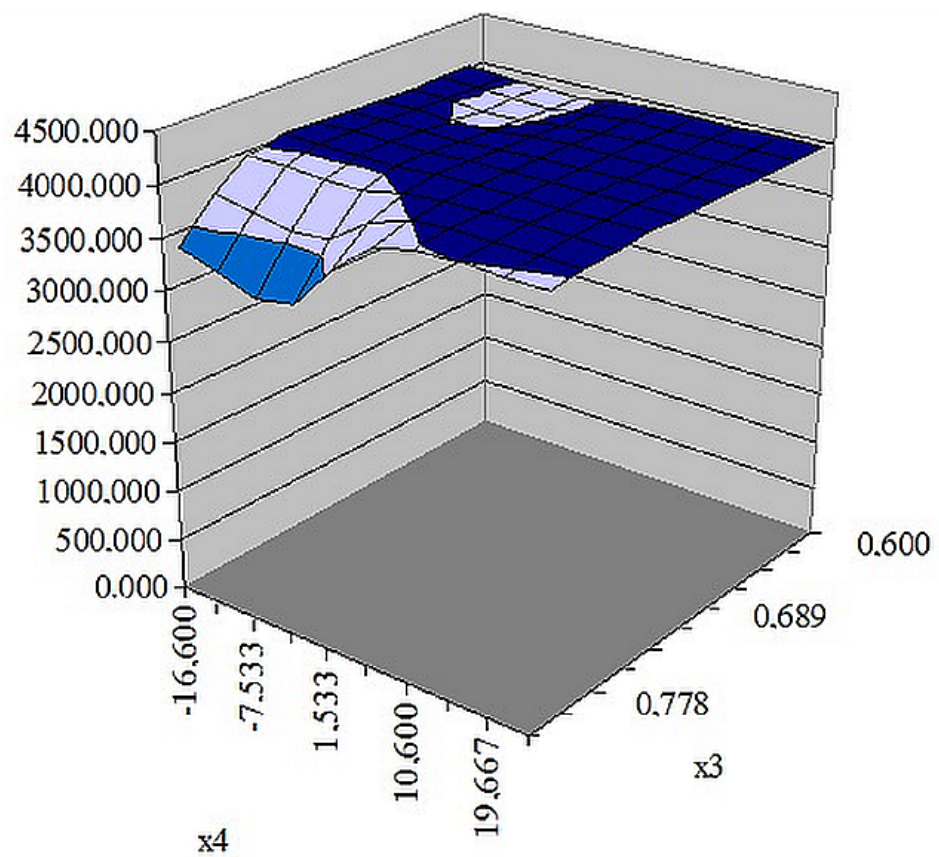

Fig. 8. GNI dependence on tax revenue share in budget revenues and real deposit interest rate

In addition, the present regulatory policy does not sufficiently encourage the banks to bring interest on deposits into conformity with inflation level, as evidenced by the high variability of this indicator. The tax revenue share in the budget revenues (X3) in turn depends on the tax burden (X2), but the growth of this indicator also shows the development of business and the reduction of the shadow economy. Objectively (X3) also depends on the degree of centralization of value added distribution in the country. In Ukraine, as shown in Fig. 8, X3 is not accompanied by GNI growth, indicating the shortcomings of distribution mechanism and lack of effectiveness of the tax system.
Thus the above research results allow, first, on the basis of the built neuro-fuzzy model, to evaluate the dependence of macroeconomic indicators, namely GDP per capita and gross national income per capita, on the indicators characterizing the economic situation of the country. Herewith this neuro-fuzzy model, unlike existing models, allows reproducing the complex nonlinear dependences.

Secondly, it is advisable to direct further research at determination of the hierarchy of factors and, on this basis, disclosure of economic events occurring in the country. 


\section{References}

1. U. N. Kiselev. Investigating a two-sector model of economic growth with the Cobb-Douglas production function, Vol. 34, issue 2, pp 66-73 (2010)

2. http://web.wordbank.org/wsite/external/dataststastic s/

3. A.K. Parida; R. Bisoi; P.K.Dash; S. Mishra. Times Series Forecasting using Chebyshev Functions based Locally Recurrent neuro-Fuzzy Information System. Int. J. Comput. Intell. Syst. Vol. 10, issue 1, pp 375 - 393 (2017).

4. V. Melnyk. Development of scientific and methodical approach to process planning innovation development of railways (Efektyvna ekonomika), $\quad$ Ed $\quad 2 \quad$ (2019) http://www.economy.nayka.com.ua/?n=2\&y=2019

5. http://www.ondd.be/website.nsf/alllweb/

6. https://europa.eu/european-union/about-eu/euro en

7. Statistical Yearbook of Ukraine, 575p. (2006)

8. M. Potapov. European experience of tariff formation in the railway sector of railway transport (Scientific Bulletin of the Odessa National Economic University). ed. 2 (265), p. 157-172 (2019)
9. O.G. Bilorus. Globalization and Development Security: Monograph, 733 p. (2001)

10. A. Davity, S. Paklina. Digital Manufacturing: New Challenges for Marketing and Business Models. Russian Management Journal, Vol. 15, issue 4, pp 537 - 552 (2017)

11. McConnell R. Campbell, Bru Stanley L. Economics: Principles, problems and politics. 1028 p. (2015)

12. N.E. Boytsun, O.M. Kiselyova, O.M. Kiselev, O.M. Prytomanova. Prediction of economic and financial processes based on neuron-fuzzy technologies, 5, P.79-93 (2005)

13. N.E. Boytsun, O.M. Kiselyova. K-model of the impact of macroeconomic factors on exports of goods to Russia, Ukraine (Economy: problems of theory and practice. Collection of sc. papers.) Issue 104, P.3-13 (2001)

14. A S. Sremac; I. Tanackov. ANFIS model for determining the economic order quantity. Decis. Mak. Appl. Manag. Eng. Vol. 1, issue 2, pp 81-92 (2018)

15. http://www.bank.gov.ua/statist/sndex.htm 